\title{
Yhteiskunnasta näkyvää taiteen työtavoilla
}

Satu Olkkonen

TIIVISTELMÄ

- Katsaus käsittelee dokumenttiteatteria tutkimusmenetelmänä ja tutkimustuloksena, sen tarjoamia sisällöllisiä mahdollisuuksia ja tutkimustiedon sensoriseen ulottuvuuteen liittyviä raportoinnin haasteita yhden tapausesimerkin kautta.

Avainsanat: taiteellinen tutkimus, taiteen tuottama tieto, dokumenttiteatteri, kanssatutkijuus

\section{ABSTRACT}

\section{MAKING SOCIETAL STRUCTURES VISIBLE BY ARTISTIC METHODS}

The review takes a look at the method of documentary theatre as a research method as well as a research outcome alongside the benefits that the context provides. Additionally, the review focuses on challenges caused by sensory aspects of the research data. This is conducted via a case study.

Key terms: artistic research, information provided by art, documentary theatre, cooperative research 


\section{Johdanto}

$\mathrm{M}$ $y$ Way - pieni kuva riittää oli ohjaamani ryhmälähtöinen dokumenttiteatteriesitys toisen asteen opinpoluista osana Tampereen yliopiston valtakunnallista Nuoret Estradille -tutkimushanketta 2015-2017 (Olkkonen 2016). Mukaan kanssatutkijoiksi, käsikirjoittajiksi ja esittäjiksi lähti kutsuttuna seitsemän nuorta kokemusasiantuntijaa ja minä taiteen pedagogiikan post docina heidän ohjaajakseen. Pohdin katsauksessa, miten esitys taiteellisena tutkimuksena on sekä tutkimusmenetelmä että tutkimustulos.

Pedagogina olen kokenut jotkut nuorisotyön pedagogiikkoihin liitetyt ilmaisut päälleliimattuina. Tällaisia taiteen työtavoille annettuja tehtäviä, tavoitteita tai ilmaisuja ovat esimerkiksi sosiaalistaminen, valtauttaminen, virikkeellistäminen, voimaannuttaminen, elämäntaitojen vahvistaminen tai itseilmaisu taiteellisen toiminnan avulla. Koska dokumenttiteatterissa on kiinnostuttu yksilön kokemasta totuudesta, kysyn voisiko taideperustainen toimintatutkimus tarjota jotain uutta yllämainittujen tulostavoitteiden rinnalle tai tilalle. Kuvaan tekstissäni lisäksi, miten omat pedagogiset taitoni järjestyivät uudelleen prosessissa, jossa en kokenut olevani varsinaisesti teatteriohjaaja vaan pikemminkin kanssatutkija.

Tutkimusmetodologisesti olen kiinnostunut peittyvien ilmiöiden tutkimisesta ja sanallistamisesta, joista esimerkkejä ja esikuvia löytyy muun muassa sosiaalitutkimuksen (esim. Hänninen, Karjalainen \& Lahti 2005; Souto, Honkasalo \& Suurpää 2015) ja nuorisotutkimuksen alueilta (esim. Hoikkala \& Kuivakangas 2017).

\section{Esitysprosessi toimintatutkimuksena}

My Way - pieni kuva riittää -esitystä yhdistää aiempiin ryhmälähtöisiin ohjauksiini se, että niissä syntynyt tieto on ollut koettua, sisäpuolista, aistillista ja yksityiskohtaista toista tietoa (Hänninen ym. 2005). Ryhmälähtöisyys tarkoittaa, että valmista käsikirjoitusta ei ole ollut, vaan se on rakentunut vähitellen harjoitusprosessin aikana. Juha Varton $(2017,34)$ taiteellinen prosessikuvaus kuvaa kohdallisesti draamakasvatuksesta peräisin olevia työtapojani. Taiteellisessa prosessissa toimiminen ei ole vain intuitiivista toimintaa vaan reflektoivaa ja korjaavaa, kokeilevaa ja tilanteille antautuvaa tekemistä, kuten Varto kuvaa taiteellista prosessia.

Osallistujien kokemuksia ja ajatuksia "myllytetään" ohjaamissani taiteellisissa prosesseissa ohjaajan ja ryhmän välisessä vuorovaikutuksessa avoi- 
mina, ei annettuina kysymyksinä. Esitykseen rakentuu tällä tavoin vastavoimia ja useita näkökulmia. Reflektiivisyydestä rakentuu fragmenttien kokonaisuus, palapeli, jonka osat liittyvät toisiinsa ja täydentävät toisiaan. Työtapoina päiväkirja, improvisaatiot ja toimintaa reflektoivat keskustelut rakentavat käsikirjoitusta. Siksi taiteellinen toiminta on sekä tutkimusmenetelmä että tutkimustulos. Tämä kokeilun, sovittamisen ja arvioinnin toimintatutkimuksen sykli toistuu useamman kerran harjoitusprosessin aikana, jonka kesto on vähintään puoli vuotta. Teatterissa työtapa on nimeltään Devising (esim. Koskenniemi 2007), jolle Hannu Heikkinen (2017) on ehdottanut suomennosta Meidän teatteri. Tällä työtavalla olen toteuttanut kaikki ryhmälähtöiset esitykset, joista mainittakoon sodan aikana samaa koulua käyneiden ja nykykoululaisten yhteistyö Otetaan vaari! 2014, poikien ja isien yhteistyöproduktio Syyntakkeettomat 2012 sekä Suomen Kulttuurirahaston Myrsky-hankkeen pilottiohjaus Halipula 2008.

\section{Esitysprosessi uutta luovana mahdollisuutena}

Kriittisyys on taiteellisten prosessien luonnollinen tila ja tarkastelutapa. Tämä johtuu siitä, että näyttämöllisyys tarjoaa mahdollisuuden tarkastella oman elämän sisältöjä kauempaa ja suurennuslasin alla - eri kontekstissa kuin eletty elämä. Dokumenttiteatteri perustuu esittäjien elämäntuntoihin, kokemuksiin, odotuksiin ja pelkoihin liittyen todellisuuteen, jota he tulkitsevat keskellä omaa elämäänsä. Tästä jännitteestä syntyy kriittisyys. Mitä enemmän sisällöt ohjaavat työryhmää ja käytettyjä työtapoja, sitä enemmän se romuttaa taiteen tekemisen tapoja ikään kuin niistä tietämättä tai välittämättä. Omakohtaisuus ja reflektiivisyys synnyttävät vapauden rakentaa uutta, ei vielä elettyä todellisuutta, joka voi todentua arkielämää kantavana voimana myöhemmin. Viimeksi mainittu ei kuitenkaan voi olla vaade, mikä sulkee alussa mainitsemani ulkoiset tavoitteet myös taidepuheesta.

Taiteellinen tutkimus tarjoaa (palvelujärjestelmissä esimerkiksi koulutuspalveluille, koulun tukipalveluille, nuorten sosiaali- ja terveyspalveluille, Kelalle, TE-toimistolle ja nuorisotyölle) tietoa, jota voi olla vaikea saavuttaa muilla tiedonkeruun menetelmillä, kuten kysymällä suoraan tai haastattelemalla. Tästä johtuen esitys tutkimusmenetelmänä sekä peittyvän, vaikeasti sanallistettavan esiintuojana voi rikastuttaa nuoruutta koskevaa valtapuhetta, malleja, toimintatapoja ja käsityksiä. Se voi purkaa niitä ennakkoluuloja, joita myös nuoret itse toisistaan, omasta elämästään, tulevaisuudestaan ja mahdollisuuksistaan luovat. Näihin asenteisiin 
törmäsimme esimerkiksi poikien produktiossa Syyntakkeettomat 2012 lukuisina nujakoina ja pukuhuonepalavereina. Samalla nuo hetket tarjosivat mahdollisuuksia eettisiin ja esteettisiin kokemuksiin, itsensä ja maailman uudelleenymmärtämiseen.

Käsikirjoituksen ryhmälähtöisyys on tapa kuulla, tuoda näkyviin ja vaikuttua siitä, mikä muutoin saattaisi peittyä. Esimerkkinä on My Way -esityksen monologi syyllisyydestä ja ahdistuksesta, jota lukion jälkeen välivuotta pitävä päätyy kokemaan.

27 päivää myöhemmin soitan TE-toimiston nuorten pisteeseen, jossa virkailijan kanssa käydään koko hakemus läpi uudestaan. Olenko tehnyt jotain väärin? Olenko tehnyt jotain väärää? Saan tietää, ettei työttömyyspäivärahaa makseta takautuvasti. Koska en ole ollut viimeisen kahden vuoden aikana riittävästi työssäoloehtoja täyttävässä työsuhteessa, haloo oon ollut lukiossa, mä oon 21 viikkoa eli yli viis kuukautta kestävällä odotusajalla, jolta ajalta ei makseta tukea, ellen osallistu TE-toimiston järjestämään työnhakuvalmennukseen. Mä en ymmärrä, mistä lähtien se 21 viikkoa lasketaan. Ja mä en tosiaankaan tiedä, mihin mä tarvitsen pakollista koulutusta, kun mulla ei oo lukemiseen, kirjoittamiseen tai kommunikaatioon liittyviä ongelmia.

6.10 minulle kerrotaan, että toinen tapa, jolla voin lyhentää 21 viikon odotusaikaa, on työkokeilu, joka voi kestää 6-12 kuukautta. Se tarkoittaa käytännössä, että oon töissä kuus tuntia päivässä, viis päivää viikossa ilman palkkaa, työttömyyspäivärahalla. Koska mä oon työtön nuori, joka ei tällä hetkellä opiskele, tää on mun velvollisuus. Tää on hallituksen määräys.

Työkokeilua vaille minä olinkin! Mä oon tehny kahta, kolmea kesätyötä ja ollu opettajan sijaisena. En hae sitten (työttömyyskorvausta), pidän mieluummin itsekunnioitukseni. (Esittäjä käpertyy lattialle, hänet kannetaan pois.) (My Way -esitystaltiointi 15.11.2016.)

My Way -esityksen subjektin näkökulmissa korostui: 1) välivuodet sisältäpäin koettuna eivät ole toisen asteen opintojen alkaessa tai päättyessä välivuosia elämästä, 2) jatko-opinnoissa ja ammatissa ei tarvitse olla kaikkien ominaisuuksien hybridi, 3) elämä kantaa epäsuorasti.

Eihän musta tanssijaa tullu, mutta hyvä kunto autto mua sähkömieheksi. Tanssin kautta koin olevani hyvä, vaikka en koulussa. Mulla riittää 
kunto rämpiä, mähän tanssin yli viis vuotta, vaikka paska keskiarvo olikin. (My Way -esitystaltiointi 15.11.2016.)

Ryhmälähtöisissä nuorten taiteellisissa prosesseissa ei ole mahdotonta olla kanssatutkija sekä säilyttää aikuisen ja kokeneen tekijän rooli työryhmässä niin, että lopputulos ei ole laskelmoiva tai ulkoapäin voimaannutettu. Tämä välttäen on mahdollista tavoittaa sisällöllisesti myös jotain muuta ja ennakoimatonta, kuin mitä alun alkaen tavoiteltiin. Esitys on tällöin linjassa taiteen ja tieteen vapaan arvoperustan kanssa - ilman, että voimavaraistamisesta tulee voimien varastamista.

- - Mutta kun he alkoivat katsoa itseään ulkoapäin, laskelmoivasti, heistä tuli samalla avuttomia, koska aikaisemman toiminnan mieli katosi, siis mielen toiminta ja toiminta mielenä lakastui. Tämä esimerkki on vakava muistutus siitä, että ihmisen olemisen ja toiminnan ulkopuolelta tuleva laskelmoiva aktivointi ja kannustaminen ulkoisen vaikutuksen tuottamiseksi helposti tuottaa aivan päinvastaisen tuloksen kuin oli tarkoitus. Voimavaraistamisen sijaan se voi suosia voiman varastamista. (Hänninen 2005, 111-112.)

\section{Positioni tutkivana journalistina}

Toisin näkeminen oli tämän prosessin suurin anti itselleni, myös sen, millaisiksi subjektien puheenvuoroiksi olen tarkoittanut aiemmat ohjaukseni erilaisten yhteisöjen tiedonvälittäjänä ilman, että olen osannut ajatella niitä taiteellisina tutkimuksina. Tämä tiedostamiseen ja inhimillistymiseen tähtäävä prosessi on tyypillistä Paulo Freiren pedagogiikasta mallia ottavalle kasvatusajattelulle (Freire 2005), jossa subjekti tarkoittaa luojaa, kokeilijaa, tietoista ja kriittistä todellisuutta koskevan tiedon rakentajaa (Hannula 2000, 3). Tämä ohjaus avasi ohjaajapedagogin rooliani erityisesti kanssatutkijuuden (Cahill 2007; Kotilainen \& Olkkonen 2018) näkökulmasta.

Dokumenttiteatterin työtavoista voi löytää yhtymäkohtia draaman työtapojen lisäksi sadutus-menetelmän (Karlsson 2003; 2005) kohtaavaan, osallistuvaan ja vastavuoroiseen toimintakulttuuriin. Tässä ohjausesimerkissä yksityiset tarinat kerrottiin tarinansa antaneen itsensä esittämänä, mikä tekee siitä erityisen sensorisen ja vaativan, ja näkemykseni mukaan myös arvokkaan. Minun vastuullani oli turvata, että esittäjillä on harjoitusprosessin aikana tullut riittävä välimatka julkituotaviin asioihin, vaikka suhde niihin oli aiemmin saattanut olla ongelmallinen. Vaikka tekijän- 
oikeudet ja omistajuus ovat tarinansa antaneella, sukellus kokijan maailmaan ei ole yksisuuntainen, vaan se on yhdessä tekemistä ja kanssatutkijuutta. Omaa rooliani työstin tutkimuspäiväkirjassani.

Moi Moi, mitä kuuluu? oli Jyväskylässä vasta päättyneen alaikäisten turvanpaikanhakijoiden valokuvanäyttely. Koen näyttelyn kokoajan, kuvajournalisti Hanna-Kaisa Hämäläisen tavoin olevani samanlaisessa roolissa. Kuinka olla vastuussa siitä, että pienistä paloista syntyy kokonaisuus. Kuinka luoda ja tukea tekijöiden vapautta. Kuinka antaa sisällön viedä ohi muodon, jonka sivuvaikutuksilla voi ravita taiteen genreä itseään, sitä mitä taiteella tehdään. Kuka itse olen ja miten itse asettaudun, jotta katsoja näkisi lukittujen taidekäsitysten ja konventionaalisten odotusten takaa sisällön, joka on jakamaton ja jossa voin olla vain vastaanottaja. Näitä Moi Moi, mitä kuuluu? -valokuvanäyttelyn rosoisessa vapaudessa mietin. Mietin myös sitä, miten taide on kaikkien. Sitä pelisilmää harjoitan ja höllennän paraikaa. Kriittiseen pedagogiikkaan orientoituneena tekijänä minun on vaikea hyväksyä mitään, mitä tarjotaan sillä ainoalla oikealla tavalla pureskeltuna tai ainoana vaihtoehtona. Objektiolosuhteissa me emme ajattele, vaan meidät ajatellaan. Tämän valta-asetelman purkaminen merkitsee jotain, myös pedagogisesti. Sitä viestiä toivon kirkastavani. Miten jättää tekijöille tulkinta totuudesta riippumatta omastani? (Ohjaajan tutkimuspäiväkirja 2016.)

Esityksissä ei näy omaelämänkerrallisuuteni, vaikka se on dialogissa, ajan tapahtumia ja ilmiöitä vasten rakentunutta. Kysymykset, joihin en ole ajatellut olevan selkeitä vastauksia, ovat kiertyneet kasvamisen edellytyksiin, uuden ja paremman maailman luomiseen alati muuttuvassa maailmassa sekä toivon pedagogiikkaan (Freire 2005; Boal 1979; 1995). Vuorovaikutuksessa syntyneeseen tietoon jää silti myös minun kädenjälkeni. Sitä ei voi mallintaa, se ei ole tekijöistään riippumatonta.

\section{Yleisön katse tiedonmuodostajana}

Dokumenttiteatterin esittäjien autenttisuus, kun esittäjät ovat siinä ja esityshetken yhteisöllisyys voivat aktivoida esittäjiä kuin myös katsojia ajattelemaan ja toimimaan yhdessä paremman maailman hyväksi. Tällöin myös katsojasta tulee kanssatutkija.

Esitystilanne yhteisöllisenä ja siten kaksisuuntaisena vuorovaikutuksena voi avartaa sitä, mitä teatterilta odotetaan, miten sitä katsotaan ja miten sii- 
tä puhutaan, vaikka esitys ei olisi osallistava. Esitystieto voi vaikuttaa nuorisokulttuuriin itseensä liitettyihin tapoihin havaita, uskoa, arvioida ja käyttäytyä sen mukaan, miten nuoret itse, tutkimustieto tai aikuiset nuoruudesta puhuvat. Aino Hannula $(2000,7)$ käyttää tästä tavoitteesta Freiren kasvatusajattelua mukaillen nimeä subjektikansalaisuus. Syrjäytyminen lienee yksi kuluneimmista yleistyksistä, jossa yksilön omat sisäiset merkityksenannot alistetaan ulkoapäin määrittelylle ja nuoret toimenpiteiden kohteiksi. Yhteiskunnasta voi tehdä näkyvää, sitä voi ottaa haltuun ja muuttaa monimuotoisemmaksi, inhimillisemmäksi ja ymmärrettäväksi taiteen avulla. Tässä sivistystahtoisuudessa olemme kaikki kasvatettavia ja kasvavia.

Mä olin vaikeesti masentunu, mitä ei ollu siellä vielä diagnosoitu, keskivaikea kautta vaikea masennus koko yläasteen, ei sitä osannu aatellakaan silloin 2004, että semmosta on olemassa. Sillon 12 vuotta sitten.

Jatkuva väsymys oli, en tiedä, tulinko kertaakaan aamulla ajoissa kouluun, tunneille, poissaoloja enemmän kuin paikallaoloja. Nukuin välitunnit jossain kellarikerroksen nurkassa. Ei ollu motivaatiota yrittääkään.

Pahat pojat oli vähän erilaisia, mä en vaan tullu tunneille. Se oli jotenkin aika normaalia. Mä olin tietyllä tapaa huomaamaton, kun mä en ollu huonoimmasta päästä numeroissa. (My Way -esitystaltiointi 15.11.2016.)

Yleisön kohtaaminen esityksen jälkeen, kun esitystilanteen välimatka ei ollut enää suojelemassa esittäjiä, olivat tämän esityskokonaisuuden kriittisin ja haavoittuvin osa. Katsojilla oli tarve kohdata esittäjät vielä esityksen päätyttyä, toisin kuin usein teatterissa, jolloin vain lähdetään pois. Varsinainen keskustelutilaisuus oli järjestetty vain ensi-illan yhteyteen, joka oli samalla tutkimusseminaari nuorisotutkimuksen ammattilaisille. Muissa esityksissä esittäjille tuntematonta yleisöä jäi runsaslukuisina odottamaan esittäjiä, vaikka salissa olivat valot ja ovet auki esityksen päättymisen merkiksi.

Katsoja voi arvioida esityskokonaisuutta, koska se on ollut minun, ammattilaisen vastuulla. Esityksen totuudenmukaisuutta käsittelevät kysymykset sekä se, mitä esitys ei käsitellyt, eivät mielestäni kuulu dokumenttiteatteriin, koska kaikkea omaan elämään liittyvää ei ole ollut tarkoitus käsitellä. Toisaalta se, että tarinansa antaneet ovat siinä katsojan silmien edessä, on kysymysten esittämisen kannalta ymmärrettävää esityksen jälkeen. 
Vaikka esittäjät seisovat yleisön edessä vahvoina siinä mielessä, että he ovat olleet rohkeita ja kykeneviä kertomaan elämänsä tapahtumista (tässä tapauksessa toisen asteen opintojen taitekohdista) ja tunnoistaan, he seisovat siinä myös aivan tavallisina nuorina, haavoittuvina ja epävarmoina.

Runsas katsojapalaute, jolle oli annettu vapaaehtoinen kirjoittamisen mahdollisuus laittamalla kynä ja paperia katsojan istuimen alle, olivat samassa linjassa tapaamisinnokkuuden kanssa. Kirjoitetut viestit eivät koskeneet niinkään itse esitystä kuin katsojien omia pohdintoja. Toki muutamat "pojat olivat söpöjä" -kommentit hivelivät ja riemastuttivat koko työryhmää. Työryhmä sai kaksisataa kirjoitettua viestiä, mikä viiteen esityskertaan nähden oli paljon, kokonaiskatsojamäärästä vajaa puolet. Esittäjien aiemmin yksin kokema muuttui kirjallisten yleisöpalautteiden myötä jaetuksi kokemukseksi jostain yleisestä.

Tää on tää juttu, jota meistä kukaan ei oo oikein halunnut mainostaa. Me seisotaan kaiken takana, ja vietäis tää esitys vaikka maan ääriin, tää on hyvä esitys. Mut se on henkilökohtanen, päästää meidän ihon alle. Se on niin totta. Pysäytyskuva elämästä. Vähän turhan totta.

En oikeestaan haluis, että kukaan tuttu näkee tätä. Toisaalta, jos oot peruskoulun tai lukion loppusuoralla, tuu kattoo, tää esitys on sulle. Jos et vielä tiedä mikä susta tulee isona, tai tuleeko mitään, tuu kattoo. Tää esitys on sulle. Jos sua hävettää olla olemassa, tai et oikein tiedä miten päin olla, tuu kattoo. Jos työskentelet nuorten kanssa, tai jos oot nuoren tai nuoreksi kasvavan vanhempi, tuu kattoo. Jos oot päättäjä, tuu kattoo. Jos oot kyllästynyt esittämiseen, ja haluat nähdä ihmisiä lavalla, tuu kattoo. Tää ei oo teatteria, tää on meidän sanoja, me itsenämme siellä. Tää vähän jännittää. (My Way -työryhmän jäsen esityksen Facebook-sivulla 9.12.2016.)

Katsoja ei välttämättä ajattele katseensa supervoimia. Kahdeksan välivuotta kymppiluokan jälkeen ei tarkoita katsojan mielessä kenties mitään hyvää. Silloin esitys lukitun näkökulman avaajana, Freiren sanoin, on sitä maailman muutostyötä yhdessä, sellaisen uuden luomista ja vahvistamista, jota on helpompi rakastaa (Hannula 2000, 124).

Tarpeeksi kun jaksaa odottaa, niin kyllä se paranee. Joskus sattuu vielä onni kohdalle. Pari viime vuotta on ollu hyviä. Teatteri tuli hyvänä asiana mun elämään. Sen jälkeen tuli asunnosta ulosmenoa. Isä on mua 
ihan mun tiedostamatta ohjaillu, saatellu tähän. Oon saanu rauhassa olla ja kasvaa. Hiljalleen on löytyny tää, mitä haluan tehdä. Tää on mielenkiintoista, haaveilen tästä ammattia. En kehtaa ihan ääneen sanoa, mutta kyllä oon ollu jo ihan tyytyväinenki. Koulun penkillä ei olis tullu mitään. Se olis kääntänyt mut pois tältä alalta. (My Way -esitystaltiointi 15.11.2016.)

Esityksen sanomallista monimuotoisuutta voi pitää tarpeellisena siksi, että yhteiskunnallinen ilmapiiri ja poliittinen ohjaus (esim. Armila, Halonen \& Käyhkö 2016) voidaan kokea myös ylivoimaisena, vaihtoehdottomana ja rakenteellisesti syrjivänä. Esitys vahvisti subjektikansalaisuutta ohi poliittisen ohjauksen.

Luetteko te mun ajatuksia? Kiitos rohkaisusta uskaltaa elää ja tehdä omat päätökset. Teiän biisit on ihan omaa luokkaansa ja haluisin kuulla niitä lisää. Oli mahtava kuulla, etten oo yksin mun ongelmien ja pelkojen kanssa. Ja että niistä voi päästä yli. Monesti tuli kyynel silmään ja kylmät väreet biisien ja esityksen aikana. Kiitos. En viitti kirjottaa tähän mun nimee, kun saatoin myöntää jotain tosi henkilökohtaista rivien välissä teille. Että oon heikko. (Katsoja 15.11.2016.)

Hyvä näytelmä aiheesta mistä Suomessa ei ole paljon puhuttu; siitä että on OK olla hukassa. [- -] räjäytti. (Katsoja 13.12.2016.)

Toiseus on oikeutuksen antamista elämän monimuotoisuudelle. Sitä luodaan mielessä, katseessa, sanoissa ja teoissa, mutta ennen kaikkea sitä tapahtuu tekijän ja katsojan välisessä tiedonmuodostuksessa - tässä ajatusten sensorisessa maastossa, josta yleisöviestit kertoivat. Esitys on monisäikeinen tiedon tuottamisen väline. Sensorisena se ei ole vähemmän vaan enemmän, vaikka se ei ole yksiselitteinen.

\section{Yhteenveto - "saitte tulevaisuuden tuntumaan mahdolliselta"}

Taiteellinen tutkimus ja kanssatutkijuus vastaa Suomen Akatemian (Nuutinen ym. 2016, 44) asettamiin tieteen haasteisiin neljällä tasolla: tiede maailmankuvan ja sivistyksen rakentajana, vaurauden ja hyvinvoinnin lähteenä, päätöksenteon perustana ja käytäntöjen kehittäjänä. Siksi on tärkeää, että taide tutkimusmenetelmänä nähdään arvokkaana 
siinä missä muutkin tieteen ja päätöksenteon tueksi tarkoitetut tiedonkeruumenetelmät.

Käyttämissäni draaman työtavoissa on ollut luonnollista tarttua vaiettuihin, marginaalisiin tai vaikeasti hahmotettaviin ilmiöihin, jopa sellaisiin, joista ajatellaan, että niistä ei voi puhua. Tutkimusmenetelmänä taideperustainen työtapa vastustaa liian helppoja malleja nuoruuden vaiheisiin ja ongelmiin tekemättä niistä kuitenkaan vaikeaa tai vähäteltävää. Tekijöiden omat sisällöt tarjoavat radikaalin, kriittisen ja eettisesti kestävän näkökulman. Tieteen kansalaistoiminta, tietoaktivismi, voi todentua tällaisessa tavanomaisuudesta poikkeavassa tutkimusympäristössä (Suurpää 2016) - tässä tapauksessa sattumanvaraisesti kootussa, toisilleen tuntemattomien joukossa ja vaikuttamaan pyrkivässä esityksessä. Esitys voi tarjota kapeisiin, kuten vaikkapa syrjäytymisen tai hyvinvoinnin käsitteisiin, monimuotoisuutta.

Tunnustan vaikeuden käsitellä esitystä esityskontekstin ulkopuolella. Miten kuljettaa esityksen omaa ääntä ja avoimuutta tieteellisessä diskurssissa, kuten vaikkapa tässä katsauksessa, luomatta uusia stereotypioita, toiseutta ja ehdottomuutta? Toiminnan raportointi ja käsitteellinen kehittäminen lupaamatta tyhjää syleileviä terveysvaikutuksia ovat nuoren taiteellisen tutkimussuunnan haaste laajemminkin. Katsojan palaute "saitte tulevaisuuden tuntumaan mahdolliselta" puolestaan kannustaa jatkamaan.

Olen ymmärtänyt taiteellisen toiminnan tässä katsauksessa tutkimusmenetelmänä ja tutkimustuloksena. Kun esityksen tutkimustulokset ovat aistillisia, kehollisia, kuultavia, nähtäviä ja liminaalisia, se tekee niiden verbalisoinnista haasteellista. Tiedon muodostuksessa maailman ja minän välinen pehmeneminen ja selkiytyminen ovat kielellisesti ehkä lähempänä tutkimusrunoutta (Foster 2017) kuin tieteen kirjoittamisen kriteereitä. Juhani Pallasmaa $(2017,26)$ kuvaa kohtaamista taiteen kanssa: "Kosketamme asioita ja käsitämme niiden olemuksen ennen kuin kykenemme puhumaan niistä."

Vaikka tieteen näkökulma ei sellaisenaan voisikaan tavoittaa taiteen moniaistillista todellisuutta, kriittinen pedagogiikka ja kriittisesti kantaa ottava toimintatutkimus, josta Juha Suoranta ja Sanna Ryynänen (2014) käyttävät nimitystä sisäpuolinen tutkimus, voivat antaa työkaluja siihen, miten monikerroksista tiedeviestintää voidaan kehittää niin, että taiteen tuottama tieto nähdään ehdottoman tarpeellisena asiantuntijatietona. Tällöin puhumme myös siitä, mitä sivistys laajasti ottaen on ja mitä se pitää sisällään. 


\section{LÄHTEET}

Armila, P., Halonen, T. \& Käyhkö, M. 2016. Reunamerkintöjä hylkysyrjästä. Nuorten elämänraameja ja tulevaisuudenkuvia harvaanasutulla maaseudulla. Helsinki: Nuorisotutkimusverkosto/ Nuorisotutkimusseura.

Boal, A. 1979. Theatre of the Oppressed. London: Pluto press.

Boal, A. 1995. The Rainbow of Desire. To Boal Method of Theatre and Therapy. London: Routledge.

Cahill, C. 2007. Doing Research with Young People: Participatory Research and the Rituals of Collective Work. Children's Geographies 5 (3), 297-312. DOI: $10.1080 / 14733280701445895$

Freire, P. 2005. Sorrettujen pedagogiikka. (Suom. Joel Kuortti). Tampere: Vastapaino.

Foster, R. 2017. Minkälainen tahansa tavallinen. Helsinki: BoD.

Hannula, A. 2000. Tiedostaminen ja muutos Paulo Freiren ajattelussa. Systemaattinen analyysi Sorrettujen pedagogiikasta. Helsinki: Helsingin yliopisto, kasvatustieteen laitos, tutkimuksia 167. Helsingin yliopiston verkkojulkaisut. Saatavissa https://core. ac.uk/download/pdf/14915381.pdf (haettu 9.8.2018).

Heikkinen, H. 2017. Ajattele toimien. Kohti draamakasvatuksen syvempää ymmärtämistä. Tampere: Draamatyö.

Hoikkala, T. \& Kuivakangas, J. (toim.) 2017. Kenen nuorisotyö? Yhteisöpedagogiikan kentät ja mahdollisuudet. Helsinki: Humanistinen ammattikorkeakoulu julkaisuja, 42. Nuorisotutkimusseura/Nuorisotutkimusverkosto, julkaisuja 196.

Hänninen, S., Karjalainen, J. \& Lahti, T. (toim.) 2005. Toinen tieto. Kirjoituksia huonoosaisuuden tunnistamisesta. Helsinki: Stakes.

Hänninen, S. 2005. Huono-osaisuuden mieli. Teoksessa S. Hänninen, J. Karjalainen \& T. Lahti (toim.) Toinen tieto. Kirjoituksia huono-osaisuuden tunnistamisesta. Helsinki: Stakes, 94-117.

Karlsson, L. 2003. Sadutus. Avain osallistuvaan toimintakulttuuriin. Jyväskylä: PSkustannus.

Karlsson, L. 2005. Lapset tiedon ja kulttuurin tuottajina. Teoksessa S. Hänninen, J. Karjalainen \& T. Lahti (toim.) Toinen tieto. Kirjoituksia huono-osaisuuden tunnistamisesta. Helsinki: Stakes, 173-194.

Koskenniemi, P. 2007. Osallistava teatteri. Devising ja muita merkillisyyksiä. Vantaa: Opintokeskus Kansalaisfoorumi.

Kotilainen, S. \& Olkkonen, S. 2018. Nuoret dokumenttiteatterin tekijät kanssatutkijoina. Kulttuuripolitiikan tutkimuksen vuosikirja 3 (1), 22-36. DOI: 10.17409/kpt.63279

Nuoret Estradille -tutkimushanke 2015-2017. Tampere: Tampereen yliopisto. Saatavissa http://www.uta.fi/cmt/tutkimus/nuoret_estradille.html (haettu 22.5.2018).

Olkkonen, S. 2016. My Way - pieni kuva riittää. Saatavissa http://blogs.uta.fi/ mediakasvatus/2016/10/31/my-way/ (haettu 22.5.2018). 
Pallasmaa, J. 2017. Ajatteleva käsi. Arkkitehtuurin eksistentiaalinen ja ruumiillinen viisaus. (Suom. Kirsi Heininen-Blomstedt). Helsinki: ntamo.

Souto, A-M., Honkasalo, V. \& Suurpää, L. 2015. Kuuntelemista, sanoittamista ja näkyväksi tekemistä - Tutkijat kiistellyn rasismiin äärellä. Teoksessa A. Häkkinen \& M. Salasuo (toim.). Salattu, hävetty, vaiettu. Miten tutkia piilossa olevia ilmiöitä. Tampere: Vastapaino, 136-162.

Suoranta, J. \& Ryynänen S. 2014. Taisteleva tutkimus. Helsinki: Into.

Suurpää, L. 2016. Tieteellisen kansalaistoiminnan arvo. Puheenvuoro Säätiöiden ja rahastojen neuvottelukunnan syysseminaarissa "Uusia ajatuksia tutkimusrahoitukseen?" 14.11.2016, Finlandia-talo, Helsinki.

Nuutinen, A., Mälkki, A., Huutoniemi, K. \& Törnroos, J. (toim.) 2016. Tieteen tila 2016. Helsinki: Suomen Akatemia. Saatavissa https://www.aka.fi/ globalassets/30tiedepoliittinen-toiminta/tieteentila/aka_tieteen_tila_yksi.pdf (haettu 9.8.2018).

Varto, J. 2017. Taiteellinen tutkimus. Mitä se on? Kuka sitä tekee? Miksi? Aalto-yliopiston julkaisusarja Taide+Muotoilu+Arkkitehtuuri 1/2017. Helsinki: Aalto ARTS Books. 